p-ISSN 1907-9850

e-ISSN 2599-2740

\title{
OPTIMASI PEMBUATAN NANOEMULSI VIRGIN COCONUT OIL
}

\author{
N.M.D. Listyorini, N.L.P.D. Wijayanti, K. Widnyani Astuti \\ Progam Studi Farmasi Fakultas Matematika dan Ilmu Pengetahuan Alam Universitas Udayana \\ *E-mail dyahlistyorini87@yahoo.com
}

\begin{abstract}
ABSTRAK
Penelitian ini mempelajari optimasi pembuatan nanoemulsi menggunakan virgin coconut oil (VCO) yang bertujuan untuk memperoleh perbandingan minyak (VCO), surfaktan dan kosurfaktan yang dapat membentuk nanoemulsi yang memenuhi persyaratan menggunakan Self Nano-Emulsifying Drug Delivery System (SNEDDS). Metode yang digunakan adalah Spontaneous Emulsification yang termasuk ke dalam SNEDDS. Perbandingan yang digunakan dalam nanoemulsi yaitu minyak (VCO): surfaktan (Cremophor RH40 atau Tween 20): kosurfaktan (PEG 400 atau etanol): fase air (akua deion) dengan perbandingan (1:8:1):5, (1:7:2):5 dan (2:7:1):5 yang menghasilkan 12 buah formula. Dilakukan uji evaluasi berupa uji stabilitas isik dan persen transmitan ke-12 formula. Diperoleh 2 formula yang dilanjutkan untuk uji zeta potensial dan ukuran partikel yaitu F2 dan F7. Uji zeta potensial F2 $(0,14 \mathrm{mV})$ dan F7 $(0,48 \mathrm{mV})$ serta uji ukuran partikel F2 $(20,8 \mathrm{~nm})$ dan F7 $(20,6 \mathrm{~nm})$. Berdasarkan hasil uji evaluasi yang dilakukan maka diperoleh dua formula yaitu F2 (VCO: Cremophor RH40: PEG 400 (1: 8:1)) dan F7 (VCO: Cremophor RH40: Etanol (1: 7: 2)) yang sesuai persyaratan untuk menghasilkan nanoemulsi yang baik.
\end{abstract}

Kata kunci: nanoemulsi, SNEDDS, VCO

\begin{abstract}
This paper discusses the optimization of nanoemulsion using virgin coconut oil (VCO), which aimed to obtain an optimum ratio of oil (VCO), surfactant and cosurfactant which can form nanoemulsion that meets the requirements using Self Nano-Emulsifying Drug Delivery System (SNEDDS). The method used was the Spontaneous Emulsification included into SNEDDS. The ratio used in nanoemulsion i.e oil (VCO): surfactant (Cremophor RH40 or Tween 20): cosurfactant (PEG 400 or ethanol): water phase (aqua deion) with ratio (1: 8: 1): 5, (1: $7: 2): 5$ and (2: 7: 1): 5 which yield 12 formulas. All of the formulas obtained were evaluated for their physical stability and percentage of transmittance. Two of the formulas i.e F2 and F7 were further evaluated for their potential zeta and particle size values. Potential zeta value of F2 was $0.14 \mathrm{mV}$ and F7 was $0.48 \mathrm{mV}$ and particle size of F2 was $20.8 \mathrm{~nm}$ and F7 was $20.6 \mathrm{~nm}$. Based on the results two formulas F2 (VCO: Cremophor RH40: PEG 400 (1: 8: 1)) and F7 (VCO: Cremophor RH40: Ethanol (1: 7: 2)) fullfill the requirements for producing a good quality of nanoemulsion.
\end{abstract}

Keywords: nanoemulsion, SNEDDS, VCO

\section{PENDAHULUAN}

Limbah logam berat bila dibuang ke Virgin Coconut Oil (VCO) diperoleh dari pemurnian minyak kelapa. VCO dapat dimanfaatkan dalam sediaan semipadat karena memiliki sifat yang baik terhadap kulit yaitu bersifat emolien, yang membuat kulit menjadi lembut dan lembab (Lestari dan Binarjo, 2013). VCO memiliki kekurangan apabila diaplikasikan secara langsung pada kulit dapat menimbulkan rasa lengket dan sulit dicuci dengan air, maka dari itu VCO dibuat dalam bentuk sediaan nanoemulsi (Stephanie, 2015).

Nanoemulsi merupakan salah satu bentuk sediaan yang stabil, transparan dan memiliki ukuran droplet yang sangat kecil biasanya di kisaran 20-200 nm. Nanoemulsi dibuat dengan mencampur fase minyak dan fase air dengan bantuan surfaktan dan kosurfaktan untuk menurunkan tegangan antarmuka (Azeem et al., 
2009; Asmarani dan Wahyuningsih, 2015; Chllepa et al., 2015).

Salah satu metode yang dapat digunakan dalam pembuatan nanoemulsi yaitu metode spontaneous emulsification (SE) yang telah dimanfaatkan dalam industri farmasi, digunakan untuk membentuk sistem pengiriman obat lipofilik. Metode ini biasanya diterapkan dalam sistem pengantaran obat yang disebut sebagai Self NanoEmulsifying Drug Delivery System (SNEDDS) (Sokolov, 2014).

Pada penelitian ini, dibuat nanoemulsi untuk aplikasi secara topikal dengan menggunakan SNEDDS. Faktor yang dapat mempengaruhi keberhasilan sistem penghantaran nanoemulsi yang dibuat yaitu sifat fisiko-kimia dan konsentrasi minyak, surfaktan dan kosurfaktan; perbandingan komponen, khususnya perbandingan minyaksurfaktan (Chime et al., 2014). Maka dari itu, pentingnya pemilihan perbandingan minyak, surfaktan dan kosurfaktan dalam formulasi nanoemulsi.

Tujuan penelitian ini adalah untuk memperoleh perbandingan minyak (VCO), surfaktan dan kosurfaktan yang dapat membentuk nanoemulsi yang memenuhi persyaratan menggunakan SNEDDS.

\section{MATERI DAN METODE}

\section{Bahan}

Bahan-bahan kimia yang digunakan dalam penelitian ini yaitu VCO (Virgin Coconut Oil), polietilen glikol 400, tween 20, etanol, cremophor RH40, akua deion diperoleh dari PT. Asian Farma dengan derajat pro analisis.

\section{Peralatan}

Alat yang digunakan dalam penelitian ini meliputi pipet ukur (IWAKI Pyrex), gelas beker (IWAKI Pyrex), botol vial $20 \mathrm{~mL}$, pipet tetes, aluminium foil, plastik ikan, timbangan analitik $\left(\mathrm{KERN}_{\mathrm{ALJ}}\right)$, ballfiller, sentrifugator ultra (SORVALL ${ }^{\circledR}$ Picco), spatel logam (OneMed), magnetik stirrer (LabTech ${ }^{\circledR}$ Corning PC-420D), dan sonikator $\left(\right.$ BRANSON $\left.^{\circledR}\right)$, spektrofotometer UV-Vis (GENESYS), zeta potensial dan ukuran partikel (Delsa ${ }^{\mathrm{TM}}$ Nano $\mathrm{C}$ Particle Analyzer, Beckman Coulter).

\section{Cara Kerja}

Pembuatan Nanoemulsi VCO

Nanoemulsi dibuat dengan cara mencampurkan VCO sebagai fase minyak dengan kosurfaktan (PEG 400 atau Etanol ) dan surfaktan (Cremophor RH40 atau Tween 20) dengan perbandingan 1: 8: 1, 1: 7: 2 dan 2: 7: 1 yang memperoleh 12 formula, masing-masing dimasukkan dalam botol vial $20 \mathrm{~mL}$, diaduk dengan pengaduk magnetik selama 2 jam dengan kecepatan $100 \mathrm{rpm}$. Campuran disonikasi menggunakan sonikator tipe bath selama 1 jam. Campuran kemudian ditambahkan dengan air deion dengan perbandingan fase minyak : air deion $=1: 5$. Campuran diaduk dengan menggoyanggoyangkan wadah hingga terbentuk nanoemulsi (Rachmawati et al., 2010).

\section{Uji Evaluasi Nanoemulsi}

a. Uji Stabilitas Fisik

Nanoemulsi disentrifugasi dengan alat sentrifugasi SORVALL ${ }^{\circledR}$ pada kecepatan 12000 rpm selama 15 menit, dilihat apakah terjadi pemisahan fase atau tidak (Rachmawati et al., 2014).

b. Uji Persen Transmitan

Persen transmitan dari sampel diukur pada panjang gelombang $650 \mathrm{~nm}$ dengan menggunakan spektrofotometer UV-Vis dengan akua deion sebagai blanko. Berdasarkan dari uji ini diperoleh sampel yang akan dilanjutkan untuk uji zeta potensial dan uji ukuran partikel.

c. Uji Zeta Potensial dan Uji Ukuran Partikel

Zeta potensial ditentukan dengan menggunakan mode electrophoretic light scattering (Delsa ${ }^{\mathrm{TM}}$ Nano C Particle Analyzer, Beckman Coulter). Sebanyak 1 g campuran minyak, surfaktan dan kosurfaktan didispersikan dalam $5 \mathrm{~mL}$ akua deion dan diukur. Ukuran partikel nanoemulsi serta indeks polidispersitas ditentukan dengan menggunakan mode photon correlation spectroscopy (Delsa ${ }^{\mathrm{TM}}$ Nano C Particle Analyzer, Beckman Coulter) (Rachmawati et al., 2014).

\section{HASIL DAN PEMBAHASAN}

Pengadukan fase minyak dengan stirrer dalam membuat sediaan nanoemulsi tidak boleh terlalu cepat atau terlalu lambat. Jika terlalu cepat 
akan terjadi turbulensi yang dapat menyebabkan ukuran globul yang terdispersi menjadi tidak rata dan juga mengakibatkan ukuran partikelnya menjadi lebih besar. Sedangkan, pengadukan yang terlalu lambat akan menyebabkan bahan-bahan sulit untuk menjadi homogen (Dewi, 2010). Campuran disonikasi menggunakan sonikator tipe bath selama satu jam yang bertujuan untuk mengecilkan ukuran partikel menuju rentang diameter nanometer (20-200 nm). Mekanisme pengecilan ukuran partikel dengan sonikasi ialah dengan memanfaatkan gelombang ultrasonik yang dapat mengubah energi listrik menjadi getaran fisik yang dapat memperkecil ukuran partikel hingga $0,2 \mu \mathrm{m}$ (Stephanie, 2015).

Pengadukan dengan menggunakan magnetic stirrer termasuk dalam metode pembuatan nanoemulsi secara spontan (Spontaneous Emulsification) dimana energi yang dibutuhkan rendah sehingga ukuran droplet yang dihasilkan kurang seragam. Pembuatan nanoemulsi secara spontan membutuhkan surfaktan dengan jumlah yang lebih banyak untuk menghasilkan sediaan dengan ukuran droplet 20-200 nm. Oleh karena itu, pada penelitian ini dilakukan kombinasi pembuatan nanoemulsi VCO dengan metode emulsifikasi energi tinggi menggunakan sonikator (Stephanie, 2015).

Tabel 1. Hasil Uji Stabilitas Fisik dan Persen Transmitan Sediaan Nanoemulsi

\begin{tabular}{ccc}
\hline Formula & Stabilitas Fisik & $\begin{array}{c}\text { Persen } \\
\text { Transmitan }\end{array}$ \\
\hline F1 & Ada pemisahan fase & $52,5 \%$ \\
F2 & $\begin{array}{c}\text { Tidak ada pemisahan } \\
\text { fase }\end{array}$ & $98,2 \%$ \\
F3 & Tidak ada pemisahan & $97,9 \%$ \\
fase & Ada pemisahan fase & $42,7 \%$ \\
F4 & Tidak ada pemisahan & $97,3 \%$ \\
F5 & fase & $22,6 \%$ \\
F6 & Ada pemisahan fase & Tidak ada pemisahan \\
F7 & fase & $98,4 \%$ \\
F8 & Ada pemisahan fase & $1,4 \%$ \\
F9 & Tidak ada pemisahan & $91,6 \%$ \\
fase & $13,4 \%$ \\
F10 & Ada pemisahan fase & Tidak ada pemisahan \\
f1 & fase & $13,5 \%$ \\
F12 & Ada pemisahan fase & $5,9 \%$ \\
\hline
\end{tabular}

Uji evaluasi yang dilakukan terhadap ke-12 sediaan nanoemulsi yaitu uji stabilitas fisik dan persen transmitan.

Sentrifugasi dilakukan untuk mengetahui ada tidaknya pemisahan fase yang terjadi akibat adanya gaya gravitasi (Stephanie, 2015). Prinsip kerja sentrifugasi adalah memisahkan partikel berdasarkan berat jenis molekulnya, dengan gaya sentrifugal yang diberikan maka partikel dengan berat jenis lebih besar akan berada dibawah dan yang memiliki berat jenis lebih kecil akan naik ke atas (Gopala, 2016).

Jika hasil persen transmitan mendekati persen transmitan air yakni $100 \%$, maka sampel tersebut memiliki kejernihan atau transparansi yang mirip dengan air (Stephanie, 2015). Semakin jernih atau semakin besar nilai transmitan maka dapat diperkirakan tetesan nanoemulsi telah mencapai ukuran nanometer. Ukuran fase terdispersi sangat mempengaruhi penampakan nanoemulsi. Bila sistem nanoemulsi memiliki ukuran globul sangat kecil dilewati cahaya, maka berkas cahaya akan diteruskan sehingga warna larutan terlihat transparan dan transmitan yang dihasilkan semakin besar. Akua deion digunakan sebagai pembanding karena tidak memiliki partikel yang menahan transmisi cahaya sehingga akan meneruskan cahaya yang melewatinya tanpa adanya efek penghamburan cahaya sehingga mempunyai nilai transmitan $100 \%$ (Wahyuningsih dan Putranti, 2015).

Pada penelitian ini ditentukan rentang persentase yang dapat dilakukan untuk uji selanjutnya yaitu berada pada rentang $98-100 \%$. Berdasarkan hasil dari persen transmitan dalam tabel diatas maka dapat disimpulkan bahwa persen transmitan formula 2 dan formula 7 yang berada antara rentang 98-100\%. Maka kedua formula tersebut yang dilanjutkan untuk diuji ukuran partikel dan zeta potensial.

Tabel 2. Hasil Uji Zeta Potensial dan Ukuran Partikel F2 dan F7 Nanoemulsi

\begin{tabular}{llll}
\hline \multirow{2}{*}{ Formula } & $\begin{array}{l}\text { Zeta } \\
\text { Potensial }\end{array}$ & Ukuran & Indeks \\
& Partikel & Polidispersitas \\
\hline F2 & $0,14 \mathrm{mV}$ & $20,8 \mathrm{~nm}$ & 0,345 \\
F7 & $0,48 \mathrm{mV}$ & $20,6 \mathrm{~nm}$ & 0,356 \\
\hline
\end{tabular}
Secara umum, nanoemulsi dengan zeta potensial - $30 \mathrm{mV}$ sampai $+30 \mathrm{mV}$ menunjukkan suatu sistem koloid yang stabil (Laili dkk, 2014). Zeta potensial adalah alat penting untuk 
mengetahui keadaan permukaan nanoemulsi dan memprediksi stabilitas jangka panjang dari nanoemulsi. Pengukuran zeta potensial juga dimaksudkan untuk mengidentifikasi muatan globul dalam nanoemulsi (Olii dkk., 2014). Hasil pengukuran zeta potensial VCO formula 2 dan 7 berturut-turut adalah $0,14 \mathrm{mV}$ dan $0,48 \mathrm{mV}$. Nilai ini memprediksikan bahwa sistem koloid nanoemulsi stabil karena memiliki nilai zeta potensial yang telah sesuai rentang yaitu antara -30 $\mathrm{mV}$ sampai $+30 \mathrm{mV}$.

Ukuran partikel sangat penting dalam pembuatan nanoemulsi. Adapun prinsip kerja alat Delsa ${ }^{\mathrm{TM}}$ Nano $\mathrm{C}$ Particle Analyzer, Beckman Coulter dalam pengukuran partikel adalah adanya hamburan cahaya yang terjadi akibat penembakan sinar laser mengenai partikel dalam sampel, cahaya yang dihamburkan mengenai partikel nanoemulsi sehingga sampel akan bereaksi menghasilkan gerak Brown, gerak acak tersebut akan dibaca oleh detektor foton pada sudut tertentu secara cepat sehingga dapat menentukan ukuran partikel, semakin kecil ukuran partikel maka akan semakin cepat gerakannya (Ristian, 2013; Stephanie, 2015).

Nanoemulsi ini ditargetkan untuk memiliki ukuran globul berada pada rentang 20-200 nm, yang dianggap aman dan dapat menyerap pada stratum korneum untuk pengiriman obat melalui kulit (Suciati, Aliyandi dan Satrialdi 2014). Indeks polidispersitas mengindikasikan keseragaman ukuran globul pada sediaan dan untuk memperkirakan rentang distribusi ukuran partikel yang ada dalam suatu sampel serta mengetahui ada tidaknya agregasi. Semakin rendah nilai indeks polidispersitas, semakin tinggi keseragaman ukuran globul pada sediaan (Olii dkk., 2014; Wahyuningsih dan Putranti, 2015). Indeks polidispersitas menggambarkan distribusi keseragaman globul-globul dalam nanoemulsi. Indeks polidispersitas yang baik memiliki nilai di bawah 0,5, sedangkan nilai di atas 0,5 menunjukkan bahwa distribusi globul adalah nonseragam (Suciati, Aliyandi dan Satrialdi 2014).

\section{SIMPULAN DAN SARAN}

\section{Simpulan}

Komposisi minyak (VCO), surfaktan dan kosurfaktan yang memenuhi persyaratan pembentukan nanoemulsi dengan menggunakan SNEDDS yaitu F2 dan F7. F2 yaitu VCO: Cremophor RH40: PEG 400 (1: 8:1) dengan karakteristik stabilitas fisik (tidak terjadi pemisahan fase dan jernih), \%transmitan (98,2 \%), ukuran partikel $(20,8 \mathrm{~nm})$ dan zeta potensial $(0,14$ mV) . F7 yaitu VCO: Cremophor RH40: Etanol (1: 7: 2) dengan karakteristik stabilitas fisik (tidak terjadi pemisahan fase dan jernih), \%transmitan $(98,4 \%)$, ukuran partikel $(20,6 \mathrm{~nm})$ dan zeta potensial $(0,48 \mathrm{mV})$.

\section{Saran}

Perlu dilakukan uji TEM (Transmission Electron Microscopy) pada formula optimum nanoemulsi.

\section{UCAPAN TERIMAKASIH}

Penulis mengucapkan terima kasih kepada semua pihak yang telah membantu dalam penyelesaian tulisan ini.

\section{DAFTAR PUSTAKA}

Asmarani, F.C. dan I. Wahyuningsih, 2015, Pengaruh Variasi Konsentrasi Tween 80 dan Sorbitol terhadap Aktivitas Antioksidan Minyak Zaitun (Oleum Olivae) dalam Formulasi Nanoemulsi, Farmasains, 2 (5): 223-228.

Azeem, A., M. Rizwan, F. J. Ahmad, Z. Iqbal, R. K. Khar, M. Aqil dan S. Talegaonkar, 2009, Nanoemulsion Components Screening and Selection: A Technical Note. AAPS Pharm Sci Tech, 10(1): 69-76.

Chime, S. A., F. C. Kenechukwu dan A. A. Attama, 2014, Nanoemulsions- Advances in Formulation, Characterization and Applications in Drug Delivery, Intech: 77126.

Chllepa, P., A. M. Eid dan N. A. Elmarzugi, 2015, Preparation and Characterization of Virgin Coconut Oil Nanoemulgel. J. Chem. Pharm. Res. 7(9): 787-793.

Dewi, R. K., 2010, Optimasi Formulasi Mikroemulsi Sediaan Hormon Testosteron Undekanoat, Skripsi, Program Studi Farmasi, Fakultas Kedokteran dan Ilmu 
Kesehatan. Universitas Islam Negeri Syarif Hidayatullah. Jakarta: 31

Gopala, J., 2016, Pengaruh Kecepatan Sentrifugasi terhadap Hasil Pemeriksaan Sedimen Urin Pagi Metode Konvensional, Skripsi, Program Studi D IV Analis Kesehatan, Fakultas Ilmu Keperawatan dan Kesehatan, Universitas Muhammadiyah.

Laili, H. N., L. Winarti dan L. O. R. K. Sari, 2014, Preparasi dan Karakterisasi Nanopartikel Kitosan-Naringenin dengan Variasi Rasio Massa Kitosan-Natrium Tripolifosfat (Preparation and Caracterization of Naringenin-Chitosan Nanoparticles with Various Mass Ratio of Chitosan-Sodium Tripolyphosphat), e-Jurnal Pustaka Kesehatan,2(2): 308-313.

Lestari, M. dan A. Binarjo, 2013, Formulasi Cold Cream Propranolol untuk Penghantaran Transdermal dengan Basis Emulsi yang Mengandung VCO (Virgin Coconut Oil). Pharmaciana, 3(2): 37-43.

Olii, A. T., J. F. Pamudji, D. Mudhakir, dan M. I. Iwo, 2014, Pengembangan, Evaluasi, dan Uji Aktivitas Antiinflamasi Akut Sediaan Nanoemulsi Spontan Minyak Jintan Hitam. Jurnal Farmasi Indonesia, 7(2): 77-83.

Rachmawati, H., D. H. Rasaputri, R. A. Susilowidodo, S. T. Darijanto, Y. C. Sumirtapura, 2010, The Influence Of Oils And Surfactants On The Formation of Self Nanoemulsifying Drug Delivery Systems (SNEDDS) Containing Therapeutic Protein. Materials Science and Technology, 247-252.
Rachmawati, H., D. K. Budiputra dan R. Mauludin, 2014, Curcumin Nanoemulsion For Transdermal Application: Formulation and Evaluation. Drug Dev Ind Pharm: 1-7.

Ristian, I., 2013, Kajian Pengaruh Konsentrasi Perak Nitrat $\left(\mathrm{AgNO}_{3}\right)$ terhadap Ukuran Nanopartikel Perak, Skripsi, Jurusan Kimia, Fakultas Matematika dan Ilmu Pengetahuan Alam, Universitas Negeri Semarang: 11.

Sokolov, Y. V., 2014, Nanoemulsion Formation By Low-Energy Methods: A Review, News of Pharmacy, 3 (79): 16-18.

Stephanie, 2015, Pengaruh Variasi Fase Minyak Virgin Coconut Oil dan Medium-Chain Triglycerides Oil terhadap Stabilitas Fisik Nanoemulsi Minyak Biji Delima dengan Kombinasi Surfaktan Tween 80 dan Kosurfaktan PEG 400, Skripsi, Fakultas Farmasi, Universitas Sanata Dharma, Yogyakarta: 19-20.

Suciati, T., A. Aliyandi dan Satrialdi, 2014, Development of Transdermal Nanoemulsion Formulation For Simultaneous Delivery of Protein Vaccine And Artin-M Adjuvant, Int J Pharm Pharm Sci. 6(6): 536-546.

Wahyuningsih, I., dan W. Putranti, 2015, Optimasi Perbandingan Tween 80 dan Polietilenglikol 400 Pada Formula Self Nanoemulsifying Drug Delivery System (SNEDDS) Minyak Biji Jinten Hitam, Pharmacy, 12(02): 223241. 